\title{
DIETARY PROTEIN IN HEMORRHAGIC BRIGHT'S DISEASE.
}

\author{
II. The Effect of Diet on Serum Proteins, Proteinuria and Tissue \\ Proteins ${ }^{1}$
}

\author{
By E. HENRY KEUTMANN AND SAMUEL H. BASSETT
}

\begin{abstract}
WITH THE TEChNICAL ASSISTANCE of GERALDINE E. JULIAN, CLARA H. PRESENT AND HELEN E. VAN ALSTINE

(From the Department of Medicine, University of Rochester School of Medicine and Dentistry and Medical Clinic of the Strong Memorial and Rochester Municipal Hospitals, Rochester, New York)
\end{abstract}

(Received for publication July 10, 1935)

The comparatively few accurate studies of the nitrogen balance which have been made during the chronic active stage of nephritis have been concerned chiefly with the quantitative aspect of the protein requirement (17). Little attention has been given to the kind of protein fed and its effect upon hypoproteinemia, proteinuria and the storage of protein in the tissues. ${ }^{2}$ The problem of hypoproteinemia is of especial interest, since no satisfactory means of increasing the concentration of the serum proteins of the nephritic has been discovered. Recently a systematic attempt has been made by Whipple and collaborators $(10,20)$ to ascertain factors governing the regeneration of plasma proteins. By repeated plasmapheresis of the dog they have shown the existence of a reserve depot containing precursors of the serum proteins. The quantity of protein released by the depot under the stimulus of depletion was often two or three times greater than the total amount of plasma protein originally present in the circulation. When the reserve had been exhausted the effect of different food proteins on the rate of regeneration was measured. The most satisfactory responses in order of decreasing potency were given by beef serum, smooth muscle, lactalbumin, boiled white of egg, skeletal muscle and liver. Owing to the excellent response of the experimental animal it seemed logical to test the effect of some of these

1 Aided by a grant from the Fluid Research Fund contributed by the Rockefeller Foundation.

${ }^{2}$ A paper published by Liu and Chu (J. Clin. Invest., $1935,14,293$ ) after the completion of this manuscript has come to our attention. Problems dealt with in their report are similar to some of those mentioned here. Since their findings do not appear to invalidate any of our observations the reader is referred to their article without further comment. proteins on the hypoproteinemia of nephritis. The general scheme has been to superimpose the test protein on standard diets with the object of determining whether the ingestion of the supplementary protein would increase the concentration of the serum proteins, either directly by increasing the rate of regeneration, or indirectly by first repairing losses from the tissue proteins. In one case the experiment was continued for seven months in order that ample time might be provided for replacement of lost body protein, while in another instance the utilization of protein was studied at different levels of caloric intake.

\section{EXPERIMENTAL PROCEDURES}

Subjects. The major part of the report is devoted to an investigation of two patients. The first was in the degenerative stage of chronic hemorrhagic Bright's disease. The second was a man whose illness was of shorter duration, and closely resembled a true nephrosis. Both patients were studied in the metabolism division of the hospital, where their diets were prepared and sampled in a manner previously described (1).

The third patient, also in the degenerative stage of chronic active hemorrhagic Bright's disease, was studied on the general medical division. His diets were prepared in the special diet kitchen of the hospital but were not sampled or analyzed.

Diets. The plan of varying the constituents of the diet differed with each subject, which necessitates a separate discussion of each case. In general the plan was to keep each patient on a control (basal) diet, from time to time superimposing the protein to be tested or additional calories in the form of carbohydrate and fat.

To provide some variety three menus were prepared for each diet. These varied slightly but had the same caloric and protein content, and were fed consecutively during each three day period. The patients thus ate the same food every third day. All of the diets were prepared without salt.

Protein supplements. With one exception, which is discussed under the case of $L$. R., the protein supplements 
were superimposed on the basal diet, giving an increase in caloric intake corresponding to the amount of the supplement. The supplements were divided into three equal portions and given together with the meals.

Lactalbumin was obtained from the Harris Laboratories. Its nitrogen content as given by the manufacturer was confirmed by analysis.

Serum protein was prepared from the serum of cattle. That given to the first patient was precipitated by the addition of one and a half volumes of alcohol, that given to the second patient by coagulation with heat at $80^{\circ} \mathrm{C}$. In each case the precipitate was washed with 95 per cent alcohol, dried in a vacuum oven at $50^{\circ} \mathrm{C}$., and reduced to a powder in a ball mill.

Liver protein was given in the form of the dried commercial residue remaining after the factors potent in the treatment of primary and secondary anemias had been extracted from fresh liver. Before feeding, the material was treated with hot alcohol in a Bloor extractor for about $\mathbf{4 8}$ hours, thus removing some pigments and rancid fats which gave the unextracted product an unpleasant odor and taste. The purified and dried residue, containing about 82 per cent protein, was reduced to a fine powder in a ball mill.

Egg white. The quantity of boiled egg white required to supply the desired amount of protein was computed from data published by Rose (21), and this amount was fed daily with the basal diet. The supplementary feedings were sampled with the other items of food and the difference between the average total nitrogen intake of these periods and the basal nitrogen intake was taken to be the amount in the supplement.

Methods. The nitrogen content of the diets, the stools and the daily urine was determined by a macro-Kjeldahl method (19). The protein content of the diets was computed as diet nitrogen $\times 6.25$, no allowance being made for the presence of nitrogen extractives in the food. Because of the many steps involved in preparing, sampling and analysing, it was found that the most reliable estimate of the amount of nitrogen eaten in each period was derived by taking the mean of all analyses for the diet concerned. The protein of the urine was determined by the micro-Kjeldahl method described by Peters and Van Slyke (19). Serum proteins were determined by the method of Howe (19). Blood for these determinations was drawn without stasis in the morning, about fourteen hours after the previous meal, and while the patients were still recumbent. Plasma volumes were determined by the dye method of Keith, Rowntree and Geraghty (12) as modified by Hooper, Smith, Belt and Whipple (11). The patients were weighed at the same time each morning after emptying the bladder and prior to the ingestion of food. The stools were separated by means of carmine given at the beginning of each metabolic period (1).

Calculation of nitrogen and protein balances. Peters and Bulger (17) have shown that it is impossible to obtain an accurate estimate of the protein balance without taking account of the changes in concentration of nonprotein nitrogen in the body fluids.

The following example is cited to illustrate the method:

In the first patient the greatest change in nonprotein nitrogen took place during Period 9. At the end of Period 8 the nonprotein nitrogen of the patient's blood was $32 \mathrm{mgm}$. per $100 \mathrm{cc}$. and he weighed 69.7 kilograms. The nonprotein nitrogen stored in his body was estimated as being $69.7 \times 0.7 \times 0.32=15.6$ grams. $^{3}$ During $\mathrm{Pe}-$ riod 9 the protein in his diet was increased and at the end of the three day period the blood nonprotein nitrogen was 52 mgm. per $100 \mathrm{cc}$. His weight being 69.8 kilograms, the nonprotein nitrogen content of the body was estimated as being $69.8 \times 0.7 \times 0.52=25.4$ grams. Therefore, the nonprotein nitrogen content of the body was estimated to have increased 9.8 grams during this period.

The balance of the calculations were as follows:

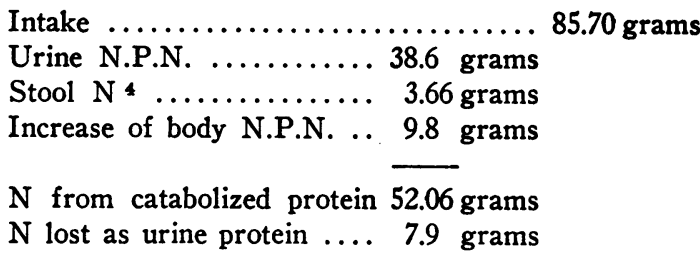

59.96 grams

Subtracting this sum from the intake ... 59.96 grams

$\mathrm{N}$ deposited as protein ........... 25.74 grams

$\mathrm{N}$ of urine protein $\ldots \ldots \ldots \ldots \ldots \ldots \ldots 7.9$ grams

$\mathrm{N}$ equivalent to total amount of protein synthesized by the body ......... 33.64 grams

The term "total protein synthesized" has been used to include the protein deposited and protein lost in the urine. The latter was either made from the diet or withdrawn from the protein stores of the body. In either case the ability of the body to recapture food protein was partly expended in counterbalancing proteinuria.

The same method of computation was used when there was a decrease of body protein either because of catabolism or proteinuria. In such instances a negative value is found in the columns designated " deposited protein." (Tables I and IV, Figures 1 and 2.)

3 This approximation may be made by assuming that the body water constitutes 70 per cent of the body weight, its nonprotein nitrogen concentration being the same as that found in the blood. Edema fluid, when present, was considered to contain 90 per cent water (17).

4 The consideration of all of the nitrogen of the stools as catabolic is probably not correct in all instances. For calculating the biological values of proteins the method of Mitchell (15) which involves the deduction of unabsorbed nitrogen from the intake is more accurate. In the present instance the deduction of unabsorbed nitrogen from the intake is not necessary since the purpose of the experiment was to determine the utilization of the foods as eaten. 
A slight error was probably involved in the correction for changes in the stores of nonprotein nitrogen, and for this reason periods which came at the time of such readjustment were never used as controls. For the most part, the calculations of nitrogen balances were not complicated by the presence of edema.

\section{PRESENTATION OF DATA}

Case Number 1. Degenerative stage of chronic hemorrhagic Bright's disease. L. R. was a 25 year old accountant who developed edema in April, 1933, eight or ten days after a severe upper respiratory infection. He was found to have proteinuria, hematuria, and cylindruria. The edema disappeared on restricting salt, but general malaise persisted until entrance to the hospital on July 31, 1933.

Physical examination at that time showed a well developed man. There was no edema. The eyegrounds were normal. The systolic blood pressure was $120 \mathrm{~mm}$. $\mathrm{Hg}$, the diastolic was $75 \mathrm{~mm}$. Hg. Purulent material could be expressed from the left tonsil. Other foci of infection were not found. Tonsillectomy was performed on August 8th, and revealed bilateral tonsillar abscesses from which hemolytic streptococci were grown. Recovery from the operation was uneventful, and at discharge he was advised to take a diet containing approximately 100 grams of protein and low in salt.

He returned for observation several times during the summer, and on October 6th, 1933 was admitted to the metabolism division of the hospital for study. The physical examination at this time revealed evidence of very slight edema of the ankles which disappeared during the first few days on a salt free diet. The systolic and diastolic blood pressures were 115 and $75 \mathrm{~mm}$. $\mathrm{Hg}$ respectively.

During the seven months of residence in the metabolism division he remained in excellent spirits and improved physically, but there was little change in the status of his renal disease. In April, a repetition of the roentgenograms of the teeth suggested periapical absorption around a lower right molar which was extracted on April 24th. Temporary increase in albuminuria followed this procedure as indicated in Table I, Period 67. Cultures of the extracted tooth yielded only diphtheroids.

Laboratory findings: Urine: August 3, 1933. About 10 grams protein in 24 hours. Addis sediment counts:

\begin{tabular}{|c|c|c|c|}
\hline & \multicolumn{3}{|c|}{$\begin{array}{l}\text { Formed elements in millions } \\
\text { per } 12 \text { hours }\end{array}$} \\
\hline & R.B.C. & $\begin{array}{l}\text { Epithelial } \\
\text { and } \\
\text { w.B.C. }\end{array}$ & Casts \\
\hline  & $\begin{array}{l}18 \\
28 \\
13 \\
15 \\
9.5\end{array}$ & $\begin{array}{r}29 \\
35 \\
8 \\
12 \\
10\end{array}$ & $\begin{array}{l}7.4 \\
1.3 \\
.75 \\
1.2 \\
.6\end{array}$ \\
\hline
\end{tabular}

Urea clearance tests:

\begin{tabular}{lrc} 
& \multicolumn{2}{c}{ per cent } \\
Aug. & 2,1933 & 42 \\
Sept. 22,1933 & 47 \\
Oct. 18,1933 & 43 \\
Nov. 15,1933 & 64 (high protein diet) \\
Dec. 29,1933 & 60 (high protein diet) \\
May & 14,1934 & 48
\end{tabular}

Blood hemoglobin content: grams per 100 cc.

$\begin{array}{lrl}\text { July } & 31,1933 & 12 \\ \text { Oct. } & 20,1933 & 13.4 \\ \text { Jan. } & 9,1934 & 13.3 \\ \text { Mar. } 10,1934 & 13.5\end{array}$

Serum protein: Aug. 1, 1933, 4.3 per cent (colorimetric method) ; September 19, 1933, 4.2 per cent (colorimetric method). Subsequent determinations (done by the method of Howe) are recorded in Table II.

The blood Wasserman reaction, blood sugar, blood nonprotein nitrogen, and $\mathrm{CO}_{2}$ capacity of the serum were normal. A culture of the blood remained sterile.

Diet. The daily basal diet given in all periods except numbers 9 to 27 inclusive (Table I and Figure 1) contained 399 grams of carbohydrate, 119 grams of fat and 67.5 grams of protein, with an energy value of 3020 calories. The sources of protein (in grams) were as follows: Vegetable, 24.3; milk, 11.6; egg, 8.1; meat, 23.5; total, 67.5. Of the meat protein 55 per cent was derived from ground beef steak, 28 per cent from ground veal steak and 17 per cent from tuna fish. Fluid intake was fixed at $2500 \mathrm{ml}$.

In Periods 9 to 27 inclusive the patient received a high protein diet containing 249 grams of carbohydrate, 134 grams of fat and 185 grams of protein, giving a caloric intake of 3030 .

The protein (in grams) came from the following sources: Vegetable, 25.9; milk, 42.9; egg, 37.1; meat, 79.1 ; total, 185. The meat fraction consisted of 79 per cent ground beef steak and 21 per cent ground veal steak.

Following Period 27 there was a series of periods during which the patient received the basal diet plus various protein supplements. These supplementary periods were alternated with a series of control periods when the basal diet alone was given. The exact order in which these followed each other is indicated in Table I and Figure 1.

Explanation of tables. In Table I and Figure 1 are given the significant data from the nitrogen balances. Periods in which an obvious change in the metabolism of nitrogen was taking place have been listed separately, while those in which conditions were found to be essentially constant have 
TABLE I

Case 1, L.R.-Protein metabolism

\begin{tabular}{|c|c|c|c|c|c|c|c|c|}
\hline \multirow[b]{2}{*}{ Period } & \multirow[b]{2}{*}{ Protein intake } & \multirow[b]{2}{*}{$\begin{array}{l}\text { Calories } \\
\text { per } \\
\text { diem }\end{array}$} & \multirow[b]{2}{*}{ Weight } & \multicolumn{5}{|c|}{ Protein metabolism } \\
\hline & & & & $\begin{array}{l}\text { In- } \\
\text { take }\end{array}$ & $\mid \begin{array}{c}\text { Catabolized } \\
\text { protein }\end{array}$ & $\begin{array}{c}\text { Urine } \\
\text { protein }\end{array}$ & $\begin{array}{c}\text { Deposited } \\
\text { protein }\end{array}$ & $\begin{array}{c}\text { Total } \\
\text { protein } \\
\text { synthe- } \\
\text { sized }\end{array}$ \\
\hline \multirow{3}{*}{$\begin{array}{r}s \text { days each } \\
1 \ldots \\
2 \text { to } 8 \ldots\end{array}$} & \multirow{3}{*}{ Basal diet 70} & \multirow{3}{*}{3020} & kgm. & $\underset{\text { per period }}{\operatorname{grams} N}$ & $\underset{\text { per period }}{\operatorname{grams} N} \boldsymbol{N}$ & $\begin{array}{l}\text { grams } N \\
\text { per period }\end{array}$ & $\begin{array}{c}\text { grams } N \\
\text { per period }\end{array}$ & $\underset{\text { per period }}{\text { grams } N}$ \\
\hline & & & 67.9 & 33.83 & 21.65 & 4.82 & 7.21 & 12.18 \\
\hline & & & 69.7 & 33.83 & 21.58 & 5.27 & 6.71 & 12.25 \\
\hline $\begin{array}{r}9 \ldots \ldots \\
10 \ldots \ldots \\
11 \ldots \ldots \\
12 \ldots \\
13 \text { to } 27 . .\end{array}$ & Diet 180 & 3030 & $\begin{array}{l}69.8 \\
70.1 \\
70.0 \\
70.5 \\
73.3 \\
\end{array}$ & $\begin{array}{l}85.70 \\
85.70 \\
85.70 \\
85.70 \\
85.70 \\
\end{array}$ & $\begin{array}{l}52.06 \\
61.32 \\
63.69 \\
66.93 \\
70.90 \\
\end{array}$ & $\begin{array}{l}7.90 \\
7.35 \\
7.26 \\
7.03 \\
6.09 \\
\end{array}$ & $\begin{array}{r}25.74 \\
17.03 \\
14.75 \\
11.74 \\
8.71 \\
\end{array}$ & $\begin{array}{l}33.64 \\
24.38 \\
22.01 \\
18.77 \\
14.80 \\
\end{array}$ \\
\hline $\begin{array}{r}28 \ldots \ldots \\
29,30 \ldots\end{array}$ & Basal diet 70, lactalbumin 50 & 3225 & $\begin{array}{l}73.7 \\
74.7\end{array}$ & $\begin{array}{l}56.13 \\
56.13\end{array}$ & $\begin{array}{l}45.30 \\
44.87\end{array}$ & $\begin{array}{l}5.03 \\
5.07\end{array}$ & $\begin{array}{l}5.80 \\
6.19\end{array}$ & $\begin{array}{l}10.83 \\
11.26\end{array}$ \\
\hline $\begin{array}{l}31,32 \ldots \\
33,34 \ldots\end{array}$ & Basal diet 70, lactalbumin 100 & 3430 & $\begin{array}{l}75.4 \\
75.6\end{array}$ & $\begin{array}{l}78.43 \\
78.43\end{array}$ & $\begin{array}{l}60.84 \\
63.26\end{array}$ & $\begin{array}{l}6.54 \\
6.76\end{array}$ & $\begin{array}{r}11.05 \\
8.41\end{array}$ & $\begin{array}{l}17.59 \\
15.17\end{array}$ \\
\hline $\begin{array}{r}35,36 \ldots \\
37 \ldots \ldots \\
38 \ldots \ldots\end{array}$ & Basal diet 70 & 3020 & $\begin{array}{l}76.2 \\
75.7 \\
75.8\end{array}$ & $\begin{array}{l}33.83 \\
33.83 \\
33.83\end{array}$ & $\begin{array}{l}30.24 \\
29.42 \\
27.34\end{array}$ & $\begin{array}{l}5.31 \\
5.18 \\
5.16\end{array}$ & $\begin{array}{r}1.72 \\
-0.77 \\
1.33\end{array}$ & $\begin{array}{l}3.59 \\
4.41 \\
6.49\end{array}$ \\
\hline $\begin{array}{l}39 \ldots \ldots \\
40 \ldots \ldots\end{array}$ & Basal diet 70, egg white (cooked) & 3005 & $\begin{array}{l}75.9 \\
75.4\end{array}$ & $\begin{array}{l}54.87 \\
54.87\end{array}$ & $\begin{array}{l}34.92 \\
38.10\end{array}$ & $\begin{array}{l}6.15 \\
7.70\end{array}$ & $\begin{array}{r}13.80 \\
9.07\end{array}$ & $\begin{array}{l}19.95 \\
16.77\end{array}$ \\
\hline 41,42 . & & & 75.8 & 54.87 & 39.90 & 7.47 & 7.50 & 14.97 \\
\hline $43,44 \ldots$ & & 3200 & 77.1 & 54.87 & 40.72 & 6.58 & 7.57 & 14.15 \\
\hline 45 to 47. & Basal diet 70, egg white 23 & 3100 & 75.9 & 44.71 & 31.90 & 5.68 & 7.13 & 12.81 \\
\hline $48 \ldots \ldots$ & Basal diet 70 & 3020 & $\begin{array}{l}76.2 \\
76.0 \\
\end{array}$ & $\begin{array}{l}33.83 \\
33.83\end{array}$ & $\begin{array}{l}26.65 \\
26.51\end{array}$ & $\begin{array}{l}5.65 \\
5.74\end{array}$ & $\begin{array}{l}1.53 \\
1.58\end{array}$ & $\begin{array}{l}7.18 \\
7.32\end{array}$ \\
\hline $\begin{array}{l}51 \ldots \ldots \\
52 \ldots \ldots \\
53 \ldots \ldots\end{array}$ & $\begin{array}{l}\text { Basal diet } 70 \\
\text { Serum protein } 10\end{array}$ & 3060 & $\begin{array}{l}76.0 \\
75.9 \\
75.8\end{array}$ & $\begin{array}{l}38.63 \\
38.63 \\
38.63\end{array}$ & $\begin{array}{l}28.91 \\
28.68 \\
28.87\end{array}$ & $\begin{array}{l}4.91 \\
6.22 \\
6.10\end{array}$ & $\begin{array}{l}4.81 \\
3.73 \\
3.66\end{array}$ & $\begin{array}{l}9.72 \\
9.95 \\
9.76\end{array}$ \\
\hline $\begin{array}{l}54 \ldots \ldots \\
55 \ldots \ldots \\
56 \ldots \ldots\end{array}$ & $\begin{array}{l}\text { Basal diet } 70 \\
\text { Serum protein } 25\end{array}$ & 3120 & $\begin{array}{l}76.0 \\
75.7 \\
75.8\end{array}$ & $\begin{array}{l}45.83 \\
45.83 \\
45.83\end{array}$ & $\begin{array}{l}32.73 \\
35.81 \\
36.10\end{array}$ & $\begin{array}{l}6.54 \\
6.26 \\
6.17\end{array}$ & $\begin{array}{l}6.56 \\
3.76 \\
3.56\end{array}$ & $\begin{array}{r}13.10 \\
10.02 \\
9.73\end{array}$ \\
\hline $\begin{array}{l}57 \ldots \ldots \\
58 \ldots \ldots \\
59 \ldots \ldots\end{array}$ & $\begin{array}{l}\text { Basal diet } 70 \\
\text { Serum protein } 50\end{array}$ & 3225 & $\begin{array}{l}75.7 \\
75.9 \\
76.1\end{array}$ & $\begin{array}{l}\mathbf{5 7 . 8 3} \\
57.83 \\
57.83\end{array}$ & $\begin{array}{l}42.81 \\
47.43 \\
49.06\end{array}$ & $\begin{array}{l}6.82 \\
6.10 \\
5.97\end{array}$ & $\begin{array}{l}8.20 \\
4.30 \\
2.80\end{array}$ & $\begin{array}{r}15.02 \\
10.40 \\
8.77\end{array}$ \\
\hline $\begin{array}{r}60 \text { to } 62 \ldots \\
63 \ldots \ldots\end{array}$ & Basal diet 70 & 3020 & $\begin{array}{l}75.2 \\
75.2\end{array}$ & $\begin{array}{l}33.83 \\
33.83\end{array}$ & $\begin{array}{l}29.43 \\
28.75\end{array}$ & $\begin{array}{l}5.30 \\
4.59\end{array}$ & $\begin{array}{r}0.90 \\
0.49\end{array}$ & $\begin{array}{l}4.40 \\
5.08\end{array}$ \\
\hline $\begin{array}{l}64 \ldots . . \\
65 \ldots . \\
66 \ldots . . \\
67 \ldots \ldots \\
\end{array}$ & $\begin{array}{l}\text { Basal diet } 70 \\
\text { Liver residue protein } 50\end{array}$ & 3225 & $\begin{array}{l}75.6 \\
75.0 \\
75.0 \\
74.7 \\
\end{array}$ & $\begin{array}{l}\mathbf{5 7 . 8 3} \\
\mathbf{5 7 . 8 3} \\
\mathbf{5 7 . 8 3} \\
\mathbf{5 7 . 8 3} \\
\end{array}$ & $\begin{array}{l}41.80 \\
44.79 \\
46.49 \\
46.47 \\
\end{array}$ & $\begin{array}{r}6.18 \\
7.64 \\
7.54 \\
10.04 \\
\end{array}$ & $\begin{array}{l}9.85 \\
5.40 \\
3.80 \\
1.32 \\
\end{array}$ & $\begin{array}{l}16.03 \\
13.04 \\
11.34 \\
11.36 \\
\end{array}$ \\
\hline $\begin{array}{l}68,69 \ldots \\
70,71 \ldots\end{array}$ & Basal diet 70 & 3000 & $\begin{array}{l}75.5 \\
75.3\end{array}$ & $\begin{array}{l}33.83 \\
33.83\end{array}$ & $\begin{array}{l}29.60 \\
28.02\end{array}$ & $\begin{array}{l}5.63 \\
4.54\end{array}$ & $\begin{array}{r}-1.40 \\
1.27\end{array}$ & $\begin{array}{l}4.23 \\
5.81\end{array}$ \\
\hline
\end{tabular}




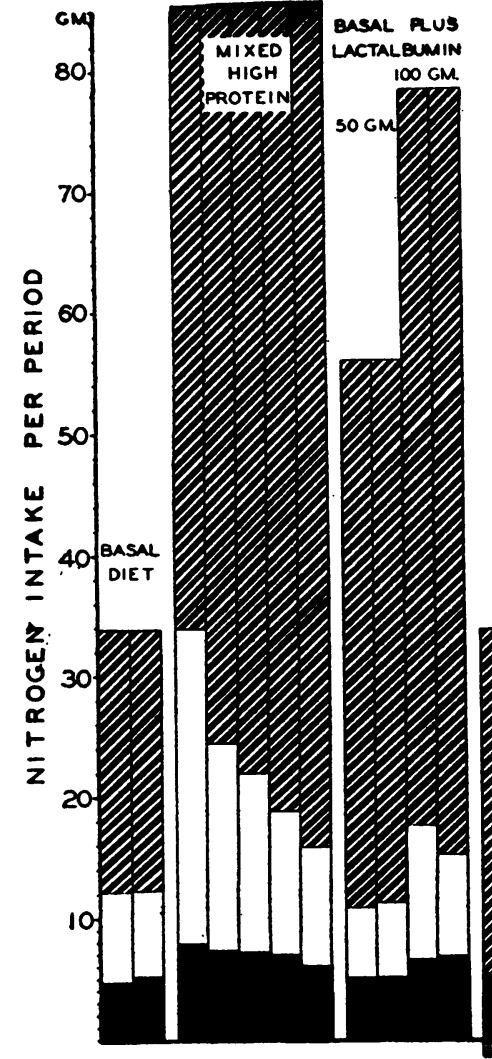

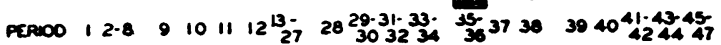



Fig. 1. CASE 1, L. R. been grouped together, and average values have been recorded.

In Table II a comparison has been made of the utilization of the various proteins or mixtures of proteins. The percentage utilization of the total amount of protein ingested was computed as follows: Average nitrogen intake, Periods 1 to 8 , 33.83 grams; average protein nitrogen in urine, 5.21 grams; average nitrogen deposited as protein, 7.03 grams; nitrogen converted into protein $(5.21+7.03), 12.24$ grams $; 12.24 \div 33.83 \times 100$ $=36.2$ per cent of the intake reconverted into protein.

As an illustration of the computation of the utilization of a supplement, Periods 39 to 42 in which 44 grams of egg white were fed daily may be taken. Average nitrogen content of the supplement, 21.04 grams ; average nitrogen of total protein synthesized, 16.67 grams; average nitrogen synthesized to protein in proximate basal periods
$(38,49,50) 7.04$ grams. The nitrogen of the supplement converted into protein is estimated as $(16.67-7.04)=9.63$ grams. Percentage of nitrogen of egg white resynthesized to protein is $9.63 \div 21.04 \times 100=45.7$ per cent.

\section{Protein metabolism}

Basal periods. During the first series of periods on the basal diet the patient deposited protein and lost protein in his urine at a fairly constant rate as indicated in Table $I$ and Figure 1 . In these twenty-four days he lost 260 grams of protein in his urine, in spite of which his body gained 338 grams of protein. The total amount of protein formed in each period was about 36 per cent of his intake as shown in Table II. During subsequent basal periods less protein was synthesized. The main decrease was in the amount deposited, while, except for the effect of lag, the amount 
TABLE II

Case 1, L.R.-Utilization of dietary and supplementary proteins

\begin{tabular}{|c|c|c|c|c|c|c|c|c|}
\hline $\begin{array}{l}\text { Description } \\
\text { of periods }\end{array}$ & $\begin{array}{c}\text { Calories } \\
\text { per } \\
\text { kgm. } \\
\text { per day }\end{array}$ & $\begin{array}{c}\text { Per cent } \\
\text { of total } \\
\text { calories } \\
\text { furnished } \\
\text { by } \\
\text { protein }\end{array}$ & $\begin{array}{c}\begin{array}{c}\text { Average } \\
\text { nitrogen } \\
\text { of } \\
\text { food }\end{array} \\
\text {. }\end{array}$ & $\begin{array}{l}\text { Average } \\
\text { nitrogen } \\
\text { of sup- } \\
\text { plement }\end{array}$ & $\begin{array}{c}\text { Average } \\
\text { total } \\
\text { nitrogen } \\
\text { intake }\end{array}$ & $\begin{array}{c}\text { Average } \\
\text { nitrogen } \\
\text { synthe- } \\
\text { sized } \\
\text { into } \\
\text { protein }\end{array}$ & $\begin{array}{l}\text { Per cent } \\
\text { of intake } \\
\text { synthe- } \\
\text { sized } \\
\text { into } \\
\text { protein }\end{array}$ & $\begin{array}{l}\text { Per cent } \\
\text { of sup- } \\
\text { plement } \\
\text { synthe- } \\
\text { sized into } \\
\text { protein }\end{array}$ \\
\hline $\begin{array}{l}\text { Basal }(1 \text { to } 8) \ldots \ldots \ldots \\
\text { Mixed high protein }(9 \text { to } 12) \ldots \ldots \ldots \\
\text { Mixed high protein }(13 \text { to } 27) \ldots \ldots \ldots\end{array}$ & $\begin{array}{l}44 \\
43 \\
43\end{array}$ & $\begin{array}{c}\text { per cent } \\
9 \\
25 \\
25\end{array}$ & $\begin{array}{c}\text { grams per } \\
\text { period } \\
33.83 \\
85.70 \\
85.70\end{array}$ & $\begin{array}{c}\text { grams per } \\
\text { period } \\
\\
51.87 \\
51.87\end{array}$ & $\begin{array}{c}\text { grams per } \\
\text { period } \\
33.83 \\
85.70 \\
85.70\end{array}$ & $\begin{array}{c}\text { grams per } \\
\text { period } \\
12.24 \\
24.78 \\
14.80\end{array}$ & $\begin{array}{c}\text { per cent } \\
36 \\
29 \\
17\end{array}$ & per cent \\
\hline  & $\begin{array}{l}40 \\
43 \\
45\end{array}$ & $\begin{array}{r}9 \\
15 \\
20\end{array}$ & $\begin{array}{l}33.83 \\
33.83 \\
33.83\end{array}$ & $\begin{array}{l}22.3 \\
44.6\end{array}$ & $\begin{array}{l}33.83 \\
56.13 \\
78.43\end{array}$ & $\begin{array}{r}7.04 \\
11.12 \\
16.18\end{array}$ & $\begin{array}{l}21 \\
20 \\
21\end{array}$ & $\begin{array}{l}18 \\
20\end{array}$ \\
\hline $\begin{array}{l}\text { Basal }(38,49,50) \ldots \ldots \ldots \ldots \ldots \ldots \\
\text { Egg white, } 44 \text { grams per diem }(39 \\
\text { to } 42) \ldots \ldots \ldots \ldots \ldots \ldots \ldots \ldots \ldots \ldots \ldots \\
\text { Egg white, } 44 \text { grams per diem }(43 \\
\text { to } 44) \ldots \ldots \ldots \ldots \ldots \ldots \ldots \ldots \ldots \ldots \\
\text { Egg white, } 23 \text { grams per diem }(45 \\
\text { to } 47) \ldots \ldots \ldots \ldots \ldots \ldots \ldots \ldots\end{array}$ & $\begin{array}{l}40 \\
40 \\
42 \\
41\end{array}$ & $\begin{array}{r}9 \\
15 \\
15 \\
12\end{array}$ & $\begin{array}{l}33.83 \\
33.83 \\
33.83 \\
33.83\end{array}$ & $\begin{array}{l}21.04 \\
21.04 \\
10.88\end{array}$ & $\begin{array}{l}33.83 \\
54.87 \\
54.87 \\
44.71\end{array}$ & $\begin{array}{r}7.04 \\
16.67 \\
14.15 \\
12.81\end{array}$ & $\begin{array}{l}21 \\
30 \\
26 \\
29\end{array}$ & $\begin{array}{l}46 \\
34 \\
53\end{array}$ \\
\hline $\begin{array}{l}\text { Basal }(49,50,63) \ldots \ldots \ldots \ldots \ldots \ldots \\
\text { Serum protein, } 10 \text { grams per diem } \\
\quad(51 \text { to } 53) \ldots \ldots \ldots \ldots \ldots \ldots \ldots \ldots \ldots \ldots \ldots \ldots \ldots \\
\text { Serum protein, } 25 \text { grams per diem } \\
\quad(54 \text { to } 56) \ldots \ldots \ldots \ldots \ldots \ldots \ldots \ldots \ldots \\
\text { Serum protein, } 50 \text { grams per diem } \\
\quad(57 \text { to } 59) \ldots \ldots \ldots \ldots \ldots \ldots \ldots\end{array}$ & $\begin{array}{l}40 \\
40 \\
41 \\
42\end{array}$ & $\begin{array}{r}9 \\
10 \\
12 \\
15\end{array}$ & $\begin{array}{l}33.83 \\
33.83 \\
33.83 \\
33.83\end{array}$ & $\begin{array}{r}4.8 \\
12.0 \\
24.0\end{array}$ & $\begin{array}{l}33.83 \\
38.63 \\
45.83 \\
57.83\end{array}$ & $\begin{array}{r}6.57 \\
9.81 \\
10.95 \\
11.40\end{array}$ & $\begin{array}{l}19 \\
25 \\
24 \\
20\end{array}$ & $\begin{array}{l}68 \\
37 \\
20\end{array}$ \\
\hline $\begin{array}{l}\text { Basal }(63,70,71) \ldots \ldots \ldots \ldots \ldots \\
\text { Liver residue protein, } 50 \text { grams per } \\
\quad \text { diem }(64 \text { to } 67) \ldots \ldots \ldots \ldots \ldots \ldots\end{array}$ & $\begin{array}{l}40 \\
42\end{array}$ & $\begin{array}{r}9 \\
15\end{array}$ & $\begin{array}{l}33.83 \\
33.83\end{array}$ & 24.0 & $\begin{array}{l}33.83 \\
57.83\end{array}$ & $\begin{array}{r}5.54 \\
12.94\end{array}$ & $\begin{array}{l}16 \\
22\end{array}$ & 31 \\
\hline
\end{tabular}

of protein lost in the urine remained the same as in earlier basal periods.

This behavior. was probably due to the fact that in the beginning the undersaturation of the tissue depots with protein permitted those reactions concerned with the formation of protein to proceed more rapidly than the reactions leading to its breakdown. During the later basal periods the tissues seem to have been more nearly saturated, and an equilibrium between incoming building stones and outgoing end products was approached.

Mixed high protein diet. Ingestion of the high protein diet led to deposition of considerably larger quantities of protein and the loss of more protein in the urine. In the first period of this diet (Period 9) about 39 per cent of the intake was utilized in formation of body protein. This was about the same proportion that was utilized with the basal diet; however, it must be pointed out that the correction for stored nonprotein nitrogen, which was calculated as 9.8 grams, may have been too small, and this would make the calculation of 39 per cent too high. In the second period which was not subject to this possibility of error, 28 per cent was utilized. Thereafter, there was a decrease in utilization for several periods until deposition and loss in the urine took place at a fairly even rate (Periods 13 to 27 ).

The fact that the urinary protein as well as the amount deposited increased suggests a greater formation of both tissue and plasma proteins. The interesting, as well as disconcerting thing, is that in spite of this increased rate of manufacture and the deposition of 1150 grams of protein in 81 days, there was no apparent change in the total amount of serum protein nor in its concentration (Table III). In fact, serum proteins appear to have been lost from the circulation as rapidly as they were supplied to it from the depots or places of manufacture. 
Lactalbumin. Although there was considerable difference in the absolute amount of protein synthesized when lactalbumin was fed in quantities of 50 and 100 grams (Table I and Figure 1), it will be noted from Table II that there was no difference in the percentage of utilization at the two levels. This is of considerable interest in view of the entirely different result obtained with egg albumin and serum protein. Unfortunately, the comparison of these supplements is open to some criticism since control periods did not precede the ingestion of lactalbumin. However, the percentage utilization of the total protein intake was the same at both levels, and furthermore, the results are still the same when the last two periods at each level are compared. The effects of lag in nitrogen and protein excretion, which might have given an erroneous result in the first two periods (28 and 31) are thus excluded.

Egg white. Cooked egg white proved to be a very efficient protein for the manufacture of serum and tissue protein as is indicated in Tables I and II. Better utilization was again noted in the earlier than in the later periods.

A slight variation in the usual method of administration was adopted in this group. During Periods 39 to 42 inclusive, enough carbohydrate and fat was withdrawn from the basal diet to offset the extra calories furnished by the supplement, so that the caloric intake was kept at the basal level. In Periods 43 and 44 these 200 calories were again added to the diet. By comparing Periods 41 and 42 with 43 and 44 in Table $I$ it may be noted that there was no change in the utilization. It is possible that the difference in caloric intake was not sufficiently large, but it is more likely that with a sufficiently high intake of carbohydrate and fat a maximum efficiency of utilization of protein is obtained which cannot be improved upon by an additional supply of nonprotein calories. Von Hoesslin's (23) data on the nitrogen balances of malnourished individuals are in agreement with this observation.

Comparison of proximate Periods 43 and 44 with 45 to 47 demonstrates that 23 gram supplements of egg white were more efficiently utilized than those of 44 grams (Table II).

Serum protein was added to the basal diet in three increments of 10,25 and 50 grams daily.
With the addition of 10 grams, utilization was the same for the three periods, 51, 52 and 53 (Table I and Figure 1). With the 25 grams and 50 gram additions, the percentage of utilization declined from period to period.

The utilization at the different levels of intake, given in Table II, is again of interest. A definitely better utilization was obtained when the smaller supplement was given, as was the case with cooked egg white.

Protein of liver residue. Successive periods had the same decrease in degree of utilization as in the case of other substances previously given as supplements. Proteinuria was greatly increased in Period 67, but apparently this was not the result of increased formation of serum protein. On the last day of Period 66 a tooth had been drawn. Although it was thought to be infected, cultures of the root failed to demonstrate the presence of pathogenic micro-organisms. On the day of extraction and for three days following, there was a marked increase in proteinuria, probably due to a transient increase in the permeability of the glomerular capillaries.

Thirty-one per cent of the liver protein supplement was utilized for building protein. This was not as good utilization as that observed when egg white was fed, yet it was better than the utilization of beef serum protein or lactalbumin.

Absorption of supplements. The average nitrogen content of the stools in basal periods was 4 grams, and during the feeding of liver protein 8.13 grams. If the increase in fecal nitrogen was due to non-absorption of a portion of the supplement, then the available supplementary nitrogen was actually 4.13 grams less per period than estimated. Introduction of this correction would make the utilization of the "absorbed portion" of the liver residue 37 per cent. The amounts of egg white, serum protein and lactalbumin which remained unabsorbed were insignificant. Corrections for non-absorption of these proteins changed the values given for their utilization less than 1 per cent.

Blood nonprotein nitrogen, serum proteins, and proteinuria. The direction and extent of change in blood nonprotein nitrogen, serum proteins, and proteinuria are given in Table III. The level of blood nonprotein nitrogen at the end of each group 
TABLE III

Case 1, L.R.

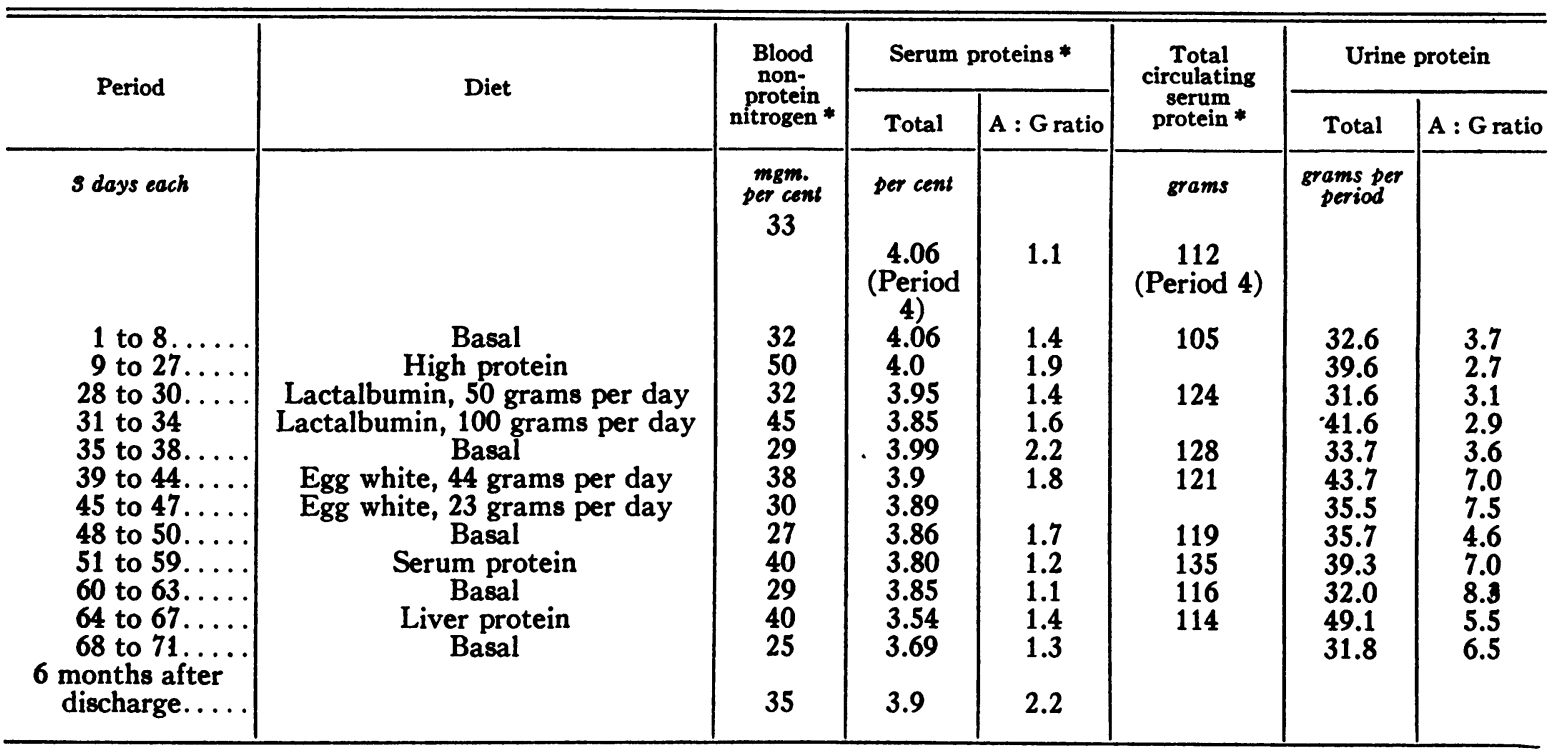

* Blood nonprotein nitrogen and serum protein determinations were made at end of each group of periods.

of periods was roughly parallel to the protein intake. Not all of the determinations which were made for the purpose of calculating the protein metabolism have been recorded in the table.

The concentration of serum proteins, as well as the total amount in circulation, remained nearly constant, and was uninfluenced either by giving large amounts of mixed proteins or by adding specific protein supplements to a basal diet. Withdrawals of blood for the first four determinations of serum proteins were made while the patient was semi-recumbent in bed. At that time the influence of posture (25) was not fully realized, so it is probable that the concentration of protein is slightly above the true basal level. With the increased loss of serum protein in the urine which followed the extraction of a tooth there seems to have been a slight decrease in its concentration in the blood, a value of 3.54 per cent obtained at the end of Period 67 being the lowest observed at any time during the patient's stay in hospital. By the end of the next group of basal periods there was again a slight rise which continued after his discharge. Serum obtained under basal conditions three months later contained 3.9 per cent protein.

Proteinuria increased whenever the protein of the diet was increased. Ingestion of egg white caused a greater increase in proteinuria than any other protein except liver residue. However, in the case of the latter the average value given in the table is unduly weighted by the presence of marked proteinuria in Period 67. We believe that this should be attributed to temporarily increased permeability of the glomerular capillaries to protein caused by extraction of the tooth. If this surmise is correct, the protein of egg white should probably be regarded as more effective in the production of proteinuria and by inference in the formation of serum protein than the other proteins.

The increase of the albumin: globulin ratio of the urinary proteins during the egg white periods indicates that formation of albumin was especially rapid. This is in keeping with the observations of Pomerenke, Slavin, Kariher and Whipple (20). The ratio and total amount excreted remained high during subsequent control periods. To account for this, one might infer that increased reserves of albumin were being discharged. Although there was a certain uniformity of the albumin: globulin ratio of the urine when entire periods or groups of periods were considered, values obtained on successive days on the same regime showed extremely great variation and were of doubtful clinical significance. 
Case 2, P. B., Degenerative Bright's disease. The patient was an unusually well preserved man aged 59 years, a cabinet maker by trade, who had always had good health until the onset of the present illness. He entered the hospital on April 4, 1934 because of gradually increasing edema of the face, the lower portion of the trunk, the genitalia, and the lower extremities. His symptoms were of five weeks' duration. Insofar as could be ascertained there was no hematuria at the onset of his illness, nor any acute infection preceding it. From the history given, his dropsy had apparently become much worse after subsisting on a milk diet and drinking large quantities of water for the three weeks immediately prior to his admission. His blood pressure was $145 / 95 \mathrm{~mm}$.
Hg. There was no evidence of cardiac failure. The face was slightly puffy; there was generalized edema of the subcutaneous tissues as high as the costal margin and moderate ascites. The teeth were poorly preserved; several were devitalized, and there was moderately severe pyorrhea. The specific gravity of the urine after restriction of fluid was 1.032. The excretion of urinary protein approximated 12 grams in 24 hours. The sediment obtained after centrifugalization contained many hyalin casts, a few granular casts and large numbers of epithelial cells and leukocytes. The sediment also contained a few cells resembling red blood cells, but these did not exceed 170,000 in twelve hours by Addis count. The standard urea clearance was 83 per cent of the normal

TABLE IV

Case 2, P.B.-Protein metabolism

\begin{tabular}{|c|c|c|c|c|c|c|c|c|}
\hline \multirow[b]{2}{*}{ Period } & \multirow[b]{2}{*}{ Protein intake } & \multirow[b]{2}{*}{$\begin{array}{c}\text { Calories } \\
\text { per } \\
\text { diem }\end{array}$} & \multirow[b]{2}{*}{ Weight } & \multicolumn{5}{|c|}{ Protein metabolism } \\
\hline & & & & $\begin{array}{l}\text { In- } \\
\text { take }\end{array}$ & $\begin{array}{c}\text { Catabolized } \\
\text { protein }\end{array}$ & $\begin{array}{c}\text { Urine } \\
\text { protein }\end{array}$ & $\begin{array}{c}\text { Deposited } \\
\text { protein }\end{array}$ & $\begin{array}{l}\text { Total } \\
\text { protein } \\
\text { synthe- } \\
\text { sized }\end{array}$ \\
\hline $\begin{array}{l}\text { s days each } \\
1 \ldots . . \\
2 \ldots \ldots \\
3 \ldots \ldots\end{array}$ & $\begin{array}{l}\text { grams per diem } \\
\text { Diet } 51\end{array}$ & 1520 & $\begin{array}{l}\text { kgm. } \\
69.7 \\
64.4 \\
61.3 \\
59.8\end{array}$ & 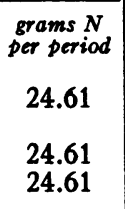 & \begin{tabular}{|c|}
$\begin{array}{c}\text { grams } N \\
\text { per period }\end{array}$ \\
34.62 \\
\\
29.1 \\
25.1 \\
\end{tabular} &  & $\begin{array}{c}\underset{\text { prams period }}{\operatorname{gram}} \\
-14.34 \\
-8.07 \\
-3.40\end{array}$ & $\begin{array}{c}\text { grams } N \\
\text { per period } \\
0 \\
0 \\
0\end{array}$ \\
\hline $\begin{array}{l}4 \ldots \ldots \\
5 \ldots \\
6 \ldots\end{array}$ & Basal diet 53 & 1930 & $\begin{array}{l}59.8 \\
59.7 \\
59.6\end{array}$ & $\begin{array}{l}25.66 \\
25.66 \\
25.66\end{array}$ & $\begin{array}{l}22.76 \\
22.23 \\
22.03\end{array}$ & $\begin{array}{l}2.44 \\
2.08 \\
1.60\end{array}$ & $\begin{array}{l}0.46 \\
1.35 \\
2.03\end{array}$ & $\begin{array}{l}2.90 \\
3.43 \\
3.63\end{array}$ \\
\hline $\begin{array}{l}11 \ldots \ldots \\
12 \ldots \ldots \\
13 \ldots \ldots\end{array}$ & $\begin{array}{l}\text { Basal diet } 56 \\
\text { Liver residue protein } 50\end{array}$ & 2814 & $\begin{array}{l}60.2 \\
60.4 \\
60.8\end{array}$ & $\begin{array}{l}51.19 \\
51.19 \\
51.19\end{array}$ & $\begin{array}{l}38.97 \\
40.22 \\
40.48\end{array}$ & $\begin{array}{l}2.50 \\
2.34 \\
2.48\end{array}$ & $\begin{array}{l}9.72 \\
8.63 \\
8.23\end{array}$ & $\begin{array}{l}12.22 \\
10.97 \\
10.71\end{array}$ \\
\hline $\begin{array}{l}14 \ldots \\
15 \ldots \\
16 \ldots \\
17 \ldots \\
\end{array}$ & Basal diet 53 & 1930 & $\begin{array}{l}60.0 \\
59.9 \\
59.4 \\
59.5\end{array}$ & $\begin{array}{l}25.66 \\
25.66 \\
25.66 \\
25.66\end{array}$ & $\begin{array}{l}23.79 \\
24.27 \\
22.68 \\
23.48\end{array}$ & $\begin{array}{l}2.07 \\
1.86 \\
1.48 \\
1.23\end{array}$ & $\begin{array}{cl}- & 0.20 \\
- & 0.47 \\
1.5 \\
0.95 \\
\end{array}$ & $\begin{array}{l}1.87 \\
1.39 \\
2.98 \\
2.18\end{array}$ \\
\hline $\begin{array}{l}18 \ldots \ldots \\
19 \ldots \ldots \\
20 \ldots \ldots \\
21 \ldots \ldots\end{array}$ & $\begin{array}{l}\text { Basal diet } 56 \\
\text { Serum protein } 50\end{array}$ & 2814 & $\begin{array}{l}59.5 \\
59.7 \\
59.9 \\
59.9\end{array}$ & $\begin{array}{l}51.19 \\
51.19 \\
51.19 \\
51.19\end{array}$ & $\begin{array}{l}39.50 \\
38.74 \\
39.02 \\
40.39\end{array}$ & $\begin{array}{l}1.51 \\
1.85 \\
1.77 \\
1.86\end{array}$ & $\begin{array}{r}10.18 \\
10.60 \\
10.40 \\
8.94 \\
\end{array}$ & $\begin{array}{l}11.69 \\
12.45 \\
12.17 \\
10.80\end{array}$ \\
\hline $\begin{array}{l}25 \ldots \ldots \\
26 \ldots \ldots \\
27 \ldots \ldots \\
28 \ldots \ldots \\
29 \ldots \ldots \\
30 \ldots \ldots\end{array}$ & $\begin{array}{l}\text { Basal diet } 56 \\
\text { Liver residue protein } 100\end{array}$ & 3019 & $\begin{array}{l}60.2 \\
60.0 \\
60.4 \\
60.4 \\
60.0 \\
60.5\end{array}$ & $\begin{array}{l}75.19 \\
75.19 \\
75.19 \\
75.19 \\
75.19 \\
75.19\end{array}$ & $\begin{array}{l}48.44 \\
56.08 \\
59.19 \\
59.14 \\
55.77 \\
58.33\end{array}$ & $\begin{array}{l}1.50 \\
1.88 \\
1.94 \\
1.97 \\
1.79 \\
1.96\end{array}$ & $\begin{array}{l}25.25 \\
17.23 \\
14.06 \\
14.08 \\
17.63 \\
14.90 \\
\end{array}$ & $\begin{array}{l}26.75 \\
19.11 \\
16.00 \\
16.05 \\
19.42 \\
16.86 \\
\end{array}$ \\
\hline $\begin{array}{l}31 \ldots \ldots \\
32 \ldots\end{array}$ & Basal diet 56 & 2609 & $\begin{array}{l}60.4 \\
60.2\end{array}$ & $\begin{array}{l}27.19 \\
27.19\end{array}$ & $\begin{array}{l}31.95 \\
26.72\end{array}$ & $\begin{array}{l}1.52 \\
1.30\end{array}$ & $\begin{array}{l}-4.76 \\
-0.83\end{array}$ & $\begin{array}{c}0 \\
0.47\end{array}$ \\
\hline
\end{tabular}


average. The concentration of the serum protein was reduced, total protein 3.6 per cent with an $A: G$ ratio of 1 . The serum contained $652 \mathrm{mgm}$. per cent of fatty acid, 452 mgm. per cent of cholesterol and $122 \mathrm{mgm}$. per cent of lecithin. There was no anemia. The basal metabolic rate was 8.0 per cent below the normal average (Aub-DuBois).

Diets. During the first six days in the hospital his daily diet provided approximately 1800 calories, and contained 110 grams of protein, $1500 \mathrm{ml}$. of fluid, and a minimum of salt. There was practically no change in his condition during this time. On the seventh day (April 10, 1934) the protein of the food was increased to 150 grams; the caloric and fluid intake remained the same. On April 13th and 14th one and one-half grams of theocin were administered, and a marked diuresis followed. On April 20th he was transferred to the metabolism division for study.

During the first three periods he received a diet which furnished 1520 calories, contained 157 grams of carbohydrate, 72 grams of fat and protein (in grams) as follows: Vegetable, 11.5; milk, 15.1; egg, 7.1 ; meat, 16.3; Total, 50. Analyses showed that the food contained
24.61 grams of nitrogen per period or 51 grams of protein per day (see Table IV). Fluid intake was fixed at $2000 \mathrm{ml}$.

Beginning with Period 4, orange juice, grape juice, sucrose and cream were added in amounts sufficient to furnish 300 calories from carbohydrate and 110 calories from fat, leaving the protein content practically undisturbed. Actual analysis showed that there was an increase of two grams of protein daily from the added cream. This diet has been designated the 1930 calorie basal diet. A supplement of 50 grams of liver residue protein was added to the above diet during Periods 7 to 10 (see Table IV and Figure 2).

During Periods 11 to 13 and 18 to 32 the caloric value of the diet was further increased, by addition of 440 calories from carbohydrate and 240 calories from fat. This has been termed the 2610 calorie basal diet. Analysis for nitrogen showed an increase above the 1900 calorie diet equivalent to 3 grams of protein daily. Fifty grams of liver residue protein were superimposed on this diet in Periods 11 to 13 , and 100 grams in Periods 25 to 30 . Fifty grams of beef serum protein were added during Periods 18 to 21 (see Table IV and Figure 2).



Fig. 2. Case 2, P. B.-Protein Metabolism. 


\section{Protein metabolism}

Periods 1 to 3. Diuresis and loss of edema which began prior to admission to the metabolism division continued during the first three periods. The total decrease in weight amounted to $23 \mathrm{kgm}$. of which $10 \mathrm{kgm}$. were lost in Periods 1 to 3 . The proteinuria accompanying the diuresis was much greater than that of subsequent periods. In part, this may have been due to a residual effect of the previous high protein feeding, and in part to an increased rate of glomerular filtration. During these three periods in which the total calories given were 1500 per diem the apparent catab-
Figure 2 and Table $\mathrm{V}$ show that more protein was deposited with twice than with one and a half times the basal caloric requirement. The utilization of this protein with the higher caloric intake was practically the same as in the case of Patient Number 1 (compare Tables II and V).

The fact that the liver residue protein, when added to the 2600 calorie diet, was equally well utilized in quantities of 50 or 100 grams was entirely unexpected and similar to the utilization of lactalbumin by Patient L. R.

Beef serum protein was utilized with about the same efficiency by this patient as by the first, perhaps very slightly better. The amount stored did

TABLE V

Case 2, P.B. Utilization of dietary and supplementary proteins

\begin{tabular}{|c|c|c|c|c|c|c|c|c|}
\hline $\begin{array}{l}\text { Basal, } 1930 \text { calories }(5,6,16,17) \ldots \\
\text { Liver residue protein, } 50 \text { grams per } \\
\text { diem }(7 \text { to } 10) \ldots \ldots \ldots \ldots \ldots \ldots \ldots\end{array}$ & $\begin{array}{l}32 \\
35.5\end{array}$ & $\begin{array}{l}\text { per cent } \\
11 \\
20\end{array}$ & $\begin{array}{c}\text { grams per } \\
\text { period } \\
25.66 \\
25.66\end{array}$ & $\begin{array}{c}\text { grams per } \\
\text { period } \\
24.0\end{array}$ & $\begin{array}{c}\text { grams per } \\
\text { period } \\
25.66 \\
49.66\end{array}$ & $\begin{array}{c}\text { grams per } \\
\text { period } \\
3.05 \\
7.08\end{array}$ & $\begin{array}{c}\text { per cent } \\
12 \\
14\end{array}$ & per cent \\
\hline $\begin{array}{l}\text { Basal, } 2610 \text { calories }(23 \text { to } 24) \ldots \ldots \\
\text { Liver residue protein, } 50 \text { grams per } \\
\text { diem (11 to } 13) \ldots \ldots \ldots \ldots \ldots \ldots \ldots \\
\text { Serum protein, } 50 \text { grams per diem } \\
\quad(18 \text { to } 21) \ldots \ldots \ldots \ldots \ldots \ldots \ldots \ldots \ldots \\
\text { Liver residue protein, } 100 \text { grams per } \\
\quad \text { diem }(25 \text { to } 30) \ldots \ldots \ldots \ldots \ldots \ldots \ldots\end{array}$ & $\begin{array}{l}43.5 \\
47.0 \\
47.0 \\
50.0\end{array}$ & $\begin{array}{c}9 \\
15.5 \\
15.5 \\
20.5\end{array}$ & $\begin{array}{l}27.19 \\
27.19 \\
27.19 \\
27.19\end{array}$ & $\begin{array}{l}24.0 \\
24.0 \\
48.0\end{array}$ & $\begin{array}{l}27.19 \\
51.19 \\
51.19 \\
75.19\end{array}$ & $\begin{array}{r}4.72 \\
11.30 \\
11.77 \\
17.49\end{array}$ & $\begin{array}{l}17 \\
22 \\
23\end{array}$ & $\begin{array}{l}27 \\
29 \\
27\end{array}$ \\
\hline
\end{tabular}

olism of protein was considerably in excess of the intake.

Basal periods. The basal caloric requirement of this patient, as determined by oxygen consumption, was 22.5 calories per kilo daily. Body weight during Periods 5 and 6 was practically constant, and activity was very moderate. The 1930 calorie diet, which furnished 32 calories per kilo per diem was sufficient for dynamic purposes and also for deposition of protein. When the caloric intake of the basal diet was increased to 43.5 calories per kilo per diem by the addition of carbohydrate and fat, the utilization of protein was increased (Table V).

Liver residue protein. Just as with the basal diet, a better utilization of the same amount of this protein was obtained when more carbohydrate and fat were available for dynamic purposes. not decline from period to period as it did in the first patient. This may indicate that the tissues of Patient Number 2 were more depleted at the time serum protein was fed.

The nonprotein nitrogen of the blood, serum proteins and proteinuria (Table VI). The nonprotein nitrogen of the blood followed the expected course, rising with the increase in the intake of protein, and falling when protein was again restricted. Disappearance of edema was attended by a rise of about 0.5 per cent in the concentration of serum proteins, and another increase of 0.56 per cent occurred when 50 grams of liver protein were added to the basal diet. Increase in the A : $G$ ratio accompanied the rise of serum protein. It is not at all certain that the higher protein intake (liver supplement of 50 grams) effected the second increase in serum protein. Dis- 
TABLE VI

Case 2, P.B.

\begin{tabular}{|c|c|c|c|c|c|c|c|}
\hline \multirow{2}{*}{ Period } & \multirow{2}{*}{ Diet } & \multirow{2}{*}{$\begin{array}{c}\text { Blood } \\
\text { non- } \\
\text { protein } \\
\text { nitrogen * }\end{array}$} & \multicolumn{2}{|c|}{ Serum proteins * } & \multirow{2}{*}{$\begin{array}{l}\text { Total } \\
\text { circulating } \\
\text { serum } \\
\text { protein * }\end{array}$} & \multicolumn{2}{|c|}{ Urine protein } \\
\hline & & & Total & A : G ratio & & Total & A : G ratio \\
\hline S days each & \multirow{8}{*}{$\begin{array}{l}1500 \text { calories......................... } \\
\text { Basal } 1900 \text { calories. } \\
\text { Basal } 1900 \text { calories }+50 \text { grams } \\
\text { liver protein } \\
\text { Basal } 2600 \text { calories }+50 \text { grams } \\
\text { liver protein } \\
\text { Basal } 1900 \text { calories } \\
\text { Basal } 2600 \text { calories }+50 \text { grams } \\
\text { serum protein } \\
\text { Basal } 2600 \text { calories } \\
\text { Basal } 2600 \text { calories }+100 \text { grams } \\
\text { liver protein } \\
\text { Basal } 2600 \text { calories } \\
\text { Mixed high protein } 3000 \text { calories }\end{array}$} & $\underset{\text { per cent }}{\operatorname{mgm} .}$ & per cent & & grams & $\begin{array}{c}\text { grams per } \\
\text { period }\end{array}$ & \\
\hline $\begin{array}{l}1 \text { to } 3 \ldots \\
4 \text { to } 6 \ldots \\
7 \text { to } 10 \ldots\end{array}$ & & $\begin{array}{l}31 \\
27 \\
18\end{array}$ & $\begin{array}{c}3.56 \\
4.08 \\
4.20\end{array}$ & $\begin{array}{l}1.2 \\
1.3 \\
1.4\end{array}$ & $\begin{array}{l}106 \\
107\end{array}$ & $\begin{array}{l}22.9 \\
12.9\end{array}$ & $\begin{array}{l}6.0 \\
8.6\end{array}$ \\
\hline 11 to $13 \ldots$ & & 28 & 4.76 & 1.6 & 117 & 13.6 & 5.6 \\
\hline $\begin{array}{l}14 \text { to } 17 \ldots \ldots \\
18 \text { to } 21 \ldots .\end{array}$ & & $\begin{array}{l}30 \\
20\end{array}$ & $\begin{array}{l}4.61 \\
4.68\end{array}$ & $\begin{array}{l}1.6 \\
1.7\end{array}$ & $\begin{array}{l}124 \\
131\end{array}$ & $\begin{array}{l}15.4 \\
10.4\end{array}$ & $\begin{array}{l}7.0 \\
4.8\end{array}$ \\
\hline $\begin{array}{l}22 \text { to } 24 \ldots \ldots \\
25 \text { to } 30 \ldots \ldots\end{array}$ & & $\begin{array}{l}23 \\
19\end{array}$ & $\begin{array}{l}4.75 \\
4.72\end{array}$ & $\begin{array}{l}1.97 \\
1.7\end{array}$ & 124 & $\begin{array}{r}10.8 \\
9.1\end{array}$ & $\begin{array}{l}4.2 \\
4.7\end{array}$ \\
\hline \multirow{3}{*}{$\begin{array}{r}31,32 \ldots \ldots \\
33,34 \ldots \ldots \\
3 \text { months after dis- } \\
\text { charge . . . . . } \\
6 \text { months after dis- } \\
\text { charge . . . . . . . }\end{array}$} & & $\begin{array}{l}30 \\
25 \\
27\end{array}$ & $\begin{array}{l}4.64 \\
4.92 \\
5.08\end{array}$ & $\begin{array}{l}2.1 \\
1.8 \\
1.7\end{array}$ & & $\begin{array}{r}11.5 \\
8.8 \\
10.2\end{array}$ & $\begin{array}{l}8.1 \\
3.0 \\
3.6\end{array}$ \\
\hline & & 33 & & 1.8 & & & \\
\hline & & & & & & & \\
\hline
\end{tabular}

* Blood nonprotein nitrogen and serum protein determinations were made at end of each group of periods.

tinct clinical improvement was noted before the feeding of liver protein was started, and inspection of successive series of basal periods shows a tendency for less and less protein to be lost in the urine. Decrease in proteinuria combined with adequate caloric intake and a reasonably abundant supply of protein of good quality was probably sufficient to permit a rise in the level of serum protein.

After the heavy loss of protein in the urine during the initial diuresis, the addition of extra protein to the diet was accompanied by increased proteinuria over proximate control periods (Table VI). This tendency was somewhat indistinct owing to the gradual decrease of proteinuria during the control periods, and was more marked in the previous patient (L. R.). The A: G ratios of the urinary proteins varied greatly and are of doubtful significance.

Case Number 3. Degenerative stage of chronic hemorrhagic Bright's disease. R. P. was a 40 year old janitor who gave a history of having had hematuria 20 years before admission and a cystitis of many years' duration. During the two weeks before admission he had developed edema of the ankles and legs and had gained ten pounds in weight. For one week he had had pain in the epi- gastrium, which gradually became more severe. Physical examination on admission revealed a subcutaneous mass in the epigastrium which was tender and not reducible. The blood pressure was $140 / 80$. The heart was slightly enlarged to the left and there was edema of the legs. The urine contained a large amount of albumin, and the sediment contained red blood cells, epithelial and white blood cells, and many casts. The blood contained 14 grams of hemoglobin per $100 \mathrm{cc} ., 4.5$ million red cells and 6300 leukocytes per cubic millimeter, and $50 \mathrm{mgm}$. per cent of nonprotein nitrogen.

The epigastric hernia was repaired under local and gas-oxygen anesthesia. After the operation, the urinary protein was found to range from 15 to 20 grams daily, and seven days after operation the total serum proteins were 4.05 per cent. He was placed on a high protein diet but because of nausea was unable to take the prescribed amount of food for about 10 days. On August 28th, twenty-one days after operation, his serum proteins were 3.1 per cent. The standard urea clearance was 63 per cent on September 2nd and 60 per cent on December 4th.

Diets. Beginning September 1st he was given a saltfree diet which furnished 3200 calories and contained 100 to 120 grams of protein. Period 1 in Table VII represents the last three days of this diet. During Periods 2 to 20 he received a basal diet which contained 60 grams of protein, and had an energy value of 3200 calories. Fifty grams of liver residue protein per diem were added to the diet during Periods 15 to 17 and 100 grams of the same protein during Periods 18 to 20 . Fluid intake was fixed at $2000 \mathrm{ml}$. 
TABLE VII

Case 3, R.P.

\begin{tabular}{|c|c|c|c|c|c|c|c|c|c|c|}
\hline \multirow{2}{*}{ Date or period } & \multirow{2}{*}{ Daily diet } & \multicolumn{2}{|c|}{ Serum proteins } & \multicolumn{2}{|c|}{ Urine protein } & \multirow{2}{*}{$\begin{array}{c}\text { Blood non- } \\
\text { protein } \\
\text { nitrogen }\end{array}$} & \multirow{2}{*}{$\begin{array}{l}\text { Approxi- } \\
\text { mate nitro- } \\
\text { gen intake }\end{array}$} & \multirow{2}{*}{$\begin{array}{c}\text { Total } \\
\text { urine } \\
\text { nitrogen }\end{array}$} & \multirow{2}{*}{$\begin{array}{c}\text { Body } \\
\text { weight }\end{array}$} & \multirow{2}{*}{ Edema } \\
\hline & & Total & $\begin{array}{l}A: \mathbf{G} \\
\text { ratio }\end{array}$ & Total & $\begin{array}{c}\text { A: }: G \\
\text { ratio }\end{array}$ & & & & & \\
\hline $\begin{array}{c}1954 \\
\text { August } 11 \ldots \\
\text { August } 28 \ldots\end{array}$ & As tolerated & $\begin{array}{l}\text { per } \\
\text { cent } \\
4.05 \\
3.06\end{array}$ & $\begin{array}{l}0.5 \\
1.0\end{array}$ & $\begin{array}{c}\text { grams per } \\
\text { diem }\end{array}$ & & $\begin{array}{c}\text { mgm. } \\
\text { per cent } \\
44 \\
38\end{array}$ & $\begin{array}{c}\text { grams per } \\
\text { diem }\end{array}$ & $\begin{array}{c}\text { grams per } \\
\text { diem }\end{array}$ & kilos & $\begin{array}{l}++++ \\
+++t\end{array}$ \\
\hline $\begin{array}{l}\text { September } 1 . \\
\text { September } \\
18 \ldots \ldots \ldots \\
\text { October } 15 . \\
\text { October } 27 . . \\
\end{array}$ & \multirow{2}{*}{$\begin{array}{l}\text { Calories } 3200 \\
\text { Protein } 100 \text { to } 120 \text { grams } \\
\text { Salt free }\end{array}$} & \multirow[t]{2}{*}{$\begin{array}{l}3.17 \\
3.10\end{array}$} & \multirow[t]{2}{*}{1.0} & $13-18$ & & $\begin{array}{l}34 \\
\\
33 \\
38\end{array}$ & $16-20$ & $8-10$ & $\begin{array}{l}68.8 \\
57.8 \\
60.5 \\
65.0\end{array}$ & $\begin{array}{c}++++ \\
0 \\
0 \\
0\end{array}$ \\
\hline $\begin{array}{c}\text { Period } 3 \text { days } \\
\text { each } \\
1 \ldots \ldots\end{array}$ & & & & $\begin{array}{c}\text { grams per } \\
\text { period } \\
56.8\end{array}$ & 4.0 & 35 & $\begin{array}{c}\text { grams per } \\
\text { period } \\
50\end{array}$ & $\begin{array}{c}\text { grams per } \\
\text { period } \\
27.9\end{array}$ & 65.4 & 0 \\
\hline $\begin{array}{c}2 \text { to } 5 \ldots \\
6 \ldots \ldots \\
7 \ldots \ldots \\
8 \text { to } 10 \ldots \\
11 \ldots \ldots \\
12,13 \\
14\end{array}$ & $\begin{array}{l}\text { Basal diet } \\
\text { Calories } 3200 \\
\text { Protein } 60 \\
\text { Salt free }\end{array}$ & 2.9 & 1.9 & $\begin{array}{c}44.3 \\
* \\
42.2 \\
* \\
42.9 \\
* \\
40.5\end{array}$ & $\begin{array}{c}4.0 \\
* \\
4.7 \\
* \\
6.0 \\
* \\
4.7\end{array}$ & 29 & $\begin{array}{l}28.0 \\
28.0 \\
28.0 \\
28.0 \\
28.0 \\
28.0 \\
28.0\end{array}$ & $\begin{array}{c}19.8 \\
* \\
22.6 \\
* \\
20.1 \\
* \\
22.2\end{array}$ & $\begin{array}{l}64.2 \\
64.8 \\
65.0 \\
65.6 \\
65.4 \\
64.8 \\
64.6\end{array}$ & $\begin{array}{l}0 \\
0 \\
\pm \\
\pm \\
\pm \\
+ \\
+\end{array}$ \\
\hline 15 to $17 \ldots$ & $\begin{array}{l}\text { Basal plus liver residue } \\
\text { protein } 50 \text { grams }\end{array}$ & 3.0 & 1.4 & 56.4 & 5.5 & 36 & 52.8 & 34.2 & 63.8 & 0 \\
\hline 18 to 20. & $\begin{array}{l}\text { Basal plus liver residue } \\
\text { protein } 100 \text { grams }\end{array}$ & 3.0 & 1.6 & 68.4 & 5.7 & 45 & 76.8 & 50.1 & 64.4 & $\mathbf{0}$ \\
\hline
\end{tabular}

* Figures for these periods not available.

\section{Protein metabolism}

The decrease in serum proteins following the operation has already been mentioned. Several factors may have been responsible for this, the most obvious of which was the inability to take an adequate diet. The operative procedure and the anesthetic may have been responsible either for additional capillary damage and consequent increased renal permeability with loss of more protein in the urine, or a decrease in the ability to manufacture serum proteins.

With the ingestion of an adequate diet (September 1st) he was able to store protein. The exact amount deposited is not known, but the difference between the nitrogen intake and urinary output in the presence of a stationary blood nonprotein nitrogen was sufficient to indicate a positive protein balance. The loss of $11 \mathrm{kgm}$. in weight after September 1st was associated with loss of edema. Subsequent gain in weight was not associated with evidence of edema, giving further proof that pro- tein was stored. In spite of this there was no rise in serum proteins.

The diet of Periods 2 to 14 inclusive contained 60 grams of protein, which, in view of the heavy proteinuria, was intended to be insufficient to maintain the concentration of serum protein at its previous level. The object of giving the lower amount of protein was to deplete the body's store of plasma protein, but the nitrogen balance observed in these periods did not point to a loss of body protein. The protein-sparing action of the high caloric diet (3200 calories) evidently permitted efficient utilization of the food protein and maintenance of nitrogen equilibrium. Proteinuria fell considerably below the previous level, and there was a very slight decrease in the concentration of serum protein. This was accompanied by slight but definite edema.

When the protein intake was increased by the addition of "liver residue" protein to the diet in Period 15, nitrogen was deposited and there was 
a marked increase in proteinuria. Edema disappeared after 3 or 4 days but the serum proteins failed to rise above 3 per cent.

\section{DISCUSSION}

The relation of tissue protein to serum protein. The filling of tissue reservoirs with protein did not influence the quantity of circulating serum protein in the nephritic patient. During seven months, Case Number 1 retained nitrogen equivalent to 2.8 kilograms of protein, yet there was no increase in the level of serum proteins, and at a given level of protein intake, proteinuria was no greater at the end than at the beginning of the experiment. The total amount of protein which can thus be deposited in the body is not known. Rubner and other investigators $(3,6,14)$ have believed it to be relatively large. Deuel et al. (6) noted the loss of 1.6 kilo of protein while subsisting for 81 days on a nearly protein-free diet. Part of the deposit appeared to be in the form of a labile fraction which was readily broken down when the intake of protein fell below an optimum level. Further evidence that deposit protein may consist of more than one fraction has been given by Pomerenke, Slavin, Kariher and Whipple (20). Their observations on the regeneration of plasma proteins in the dog indicates the necessity of drawing a distinction between the total reserve or deposit protein and that fraction of it which is readily available for conversion into plasma protein. Using the data which they have given one may estimate that an average sized man might have as much as $\mathbf{5 0 0}$ grams of serum protein held in special reservoirs. It is to be recognized, of course, that species differences may invalidate such a computation. The observations made on the nephritic patient give us no definite evidence that any of the retained protein was used to build up a reserve to protect the body against further depletion of serum proteins. On the other hand, there is no proof that all or part of the reserve set up in Case 1 could not have been used to help maintain the existing level of the serum proteins.

The ability of nephritic patients to synthesize serum protein. In a discussion of the problem of hypoproteinemia Bloomfield (2) has cited arguments in favor of an impaired or injured mechanism for regeneration of serum protein in the nephritic. On the basis of available information Weech, Goettsch and Reeves (24) are inclined to agree with Bloomfield that the loss and lack theory is insufficient to account for hypoproteinemia, but they consider it hardly justifiable to assume that there is an injury to the blood proteinforming mechanism. Although from the observations at hand one can not tell whether any of the protein being deposited in the tissues of Patients 1 and 2 served as a defense against further depletion of the serum proteins, it is possible by measurement of proteinuria to produce evidence of a very active regenerative process in Patients 1 and 3. To refer again to Case 1 , it will be noted that during 213 days the patient was able to produce 5.5 kilograms of protein, beside meeting the ordinary requirements of his protein metabolism. Of this amount 2.8 kilograms were held in the tissues, and 2.7 kilos escaped in the urine. Since a considerable degree of undersaturation of the tissues with protein is indicated in the initial periods, it is probable that any reserve stores of serum protein had been depleted before these studies were begun. As a consequence the regenerated serum protein appears to have come from the protein of the food. During the stated interval of time the construction of new serum protein, therefore, amounted to about thirteen times the total quantity of circulating serum protein in a normal individual of similar weight. As the patient's total circulating serum protein was only about half as great as that of the normal, regeneration in his case was sufficiently rapid to have replaced all of his serum protein within ten days. Likewise Case 3, who had marked hypoproteinemia, was able to regenerate about 14 grams of serum protein per diem. The diet in the latter instance contained only 60 grams of mixed protein daily, and after the requirements of metabolism and proteinuria had been met there was little protein available for deposition in the tissues. At no time was there a negative nitrogen balance, and no appreciable decrease in the concentration of serum protein occurred. The catabolism of protein was 0.72 gram per kilo per day showing an efficient utilization of food protein.

The hypothesis of defective regeneration of serum proteins in nephrotic states seems to have been substantiated to a certain extent in Case 2 . 
The diet appears to have furnished the calories and protein required for effective replacement of tissue protein, and the losses of protein in the urine gradually became much less than in Cases 1 and 3 , yet the increase in circulating serum protein was exceedingly slow. Before ascribing the small increase in circulating protein to faulty regeneration, a number of other possibilities must be considered. As Whipple and his collaborators have shown $(10,20)$, a reserve depot of serum protein or readily available precursors exists in the body. It is hardly possible to conceive of replacement of serum protein without some replacement of parent material. That such deposition occurred is suggested by delayed increase in proteinuria following addition of supplementary protein to the diet and by excess excretion of urinary protein for a varying number of days after the supplement was discontinued. A similar lag has been noted in the dog (10).

Little as yet is known of the mechanisms which stimulate the formation of serum protein. Evidently artificial lowering of the concentration by removal of the protein is an effective stimulus to the regenerative process in the normal dog (10). The increased catabolism of protein incident to starvation in one of Weech's dogs (24) suffering from nutritional hypoproteinemia seems to have provided the requisite stimulus for regeneration of serum protein. This result is diametrically opposed to the result obtained in a somewhat similar experiment reported by Pomerenke, Slavin, Kariher and Whipple (20). In the latter instance, the reserves of plasma protein had been depleted prior to fasting, and only minimal formation of new plasma protein occurred. One might suspect, therefore, that in the case of Weech's dog, reserves of the precursors of serum protein still existed, and that the utilization of body protein for dynamic purposes in some way liberated them to replace losses from the blood.

Clinical observations have shown that the proteinuria accompanying a concentration of serum protein of 3 per cent is generally much greater than that accompanying a concentration of 5 per cent (9). One might conjecture that one of the reasons that a particular degree of hypoproteinemia is maintained over a considerable period of time is because the stimulus to regeneration is just sufficient to offset the losses in the urine. Until the rate of escape of protein decreases either as a result of improvement in the renal lesion or because the number of functioning glomeruli has been greatly reduced (renal failure) little change in the circulating serum protein is to be expected. Nevertheless, it is difficult to reconcile this view with other known facts. It has already been shown that different kinds of food protein cause different rates of regeneration in the $\operatorname{dog}(10,20)$. The evidence submitted here appears to point quite definitely to an increased rate of formation of serum protein in the periods in which the intake of protein was increased, but with respect to the animal proteins tested, quantity seems to have been fully as important a factor as quality in increasing proteinuria. If the production of serum protein can be increased by the means indicated, it is remarkable that an increased rate of manufacture should have been completely offset by the increased rate of escape of protein in the urine. It is extremely doubtful whether the greater proteinuria can be attributed to further injury to the kidney. Tests of renal function as well as general improvement in the clinical condition of these and other patients $(8,13)$ do not point to increased renal damage.

Since the albumin fraction appears to have been relatively more depleted than the globulin, it might be supposed that high protein diet would lead to a greater formation of albumin than globulin and hence to a greater escape of the smaller albumin molecule in the urine. Were this true, the urinary ratio of albumin to globulin should have risen in high protein periods. Actually, variations in the ratio were so inconsistent that they failed to lend any support to this hypothesis, some of the highest ratios being observed when the protein intake and proteinuria were the least. The diuretic effect of high protein diets has been shown to cause increased renal blood flow (22) and is probably a real factor in increasing the output of protein in the urine. Some preliminary experiments with diuretin and urea in Case 3 showed that proteinuria definitely increased when these substances were administered. While it does not seem feasible at present to attribute the hypoproteinemia of nephritis to any single influence, the amount of protein lost in the urine seems to have had an im- 
portant effect on the degree of hypoproteinemia. The two patients (Cases 1 and 3 ) who showed a high grade of proteinuria had persistently low concentrations of serum protein and were unable to increase the amount of blood protein in circulation. The increase in serum protein in Case 2 was apparently closely related to decreasing losses of protein in the urine. Again there was no obvious relationship between high protein intakes and the level of the serum proteins.

Lag in excretion of nitrogen and protein requires brief mention. Falta and others $(7,4,14)$ have found that in normal individuals considerable lag in the excretion of nitrogen may follow the superposition of certain proteins on a standard diet. Lag has been attributed to the manufacture of deposit protein and its subsequent utilization in metabolism when the supplementary protein feeding was stopped. Of the proteins tested, egg white was found to produce the longest lag. This is of interest in connection with the ingestion of cooked egg white by Case 1 . The greatest delay in return of proteinuria to the basal level occurred after feeding this protein.

The efficiency of utilization of supplementary protein at different levels of intake varied considerably. It has already been mentioned that increasing increments of egg white and serum protein were less well utilized, while the efficiency of utilization of 50 and 100 gram supplements of either lactalbumin or liver protein remained constant. The lack of uniformity in these results suggests, that, providing the energy furnished by carbohydrate and fat is sufficient, the utilization of dietary proteins depends upon the nature of the protein required by the body and the quantity and relative proportions of the amino acids furnished by the metabolic mixture.

Mitchell $(15,16)$ found that there was a decrease in the biological value of protein for growing rats when the concentration in the diet was increased from 5 to 10 per cent. He attributed this decrease partly to less effective utilization for growth than for maintenance, the maintenance requirements being met first and such of the available amino acids as were left then being employed to form body protein. In addition, when higher concentrations of protein were fed, the concentration of amino acids in the nutrient mixture sur- rounding the cells was thought to have increased, and thus led to greater utilization of protein for dynamic purposes.

The data of von Hoesslin (23) on malnourished individuals are more comparable to the results obtained in nephritis than are animal experiments. He found in most instances that increasing increments of food protein were less effectively utilized but cites at least one example where the percentage of nitrogen retained when 187 grams of protein were fed daily was greater than the percentage retained when only 97 grams were fed. Each diet provided nearly the same number of calories in the form of carbohydrate and fat.

As Mitchell has suggested, one can hardly expect the biological value of a protein to be the same for all functions and the phenomena observed in our patients may not be true of other conditions. The ability to utilize some proteins more effectively than others may have depended upon the large demand for a mixture of amino acids suited to the formation of plasma protein and its precursors. Those proteins, then, which were most effectively utilized provided in addition to the amino acids needed for regeneration of plasma protein a suitable mixture of building stones for formation of deposit protein.

\section{SUM MARY}

The protein balances of three patients with degenerative Bright's disease, heavy proteinuria and hypoproteinemia have been measured. The method of procedure was to superimpose on basal diets different proteins or additional calories in the form of carbohydrate and fat.

When the caloric and protein contents of the diet were sufficient, all of the patients stored large amounts of protein, an indication of previous depletion of their tissue proteins.

In the case of Patient 2, when the intake of protein approximated 0.8 gram per kilo daily, a diet with a caloric content of one and one-half times the basal requirement permitted some storage of protein. Further additions of carbohydrate and fat sufficient to raise the caloric content of the diet to twice the basal requirement appreciably increased the deposition of protein.

The sum of the protein stored plus protein lost 
in the urine was taken as the total amount of protein synthesized in the body from food. The percentage utilization of the proteins of the food was computed on this basis (Tables II and V).

Small supplementary feedings of egg white and serum protein (supplements of 10 to 25 grams) were more efficiently utilized than supplements of 50 grams. Lactalbumin and the protein of liver residue were utilized equally well when either 50 or 100 grams were fed daily.

When the protein intake was increased, proteinuria increased. This has been considered as evidence pointing to an increased rate of synthesis of serum protein. The escape of a larger amount of protein in the urine may have been due to the increased rate of blood flow through the kidneys resulting from the diuretic action of the high protein diet.

While ingesting a high protein diet, two of the patients failed to show any increase in the total amount of circulating serum protein although they were able to deposit large amounts of protein in the body. In both instances the intensity of the renal disease, as indicated by the character and amount of formed elements in the urinary sediment, remained stationary.

The concentration of the serum proteins of the third patient (Case 2) increased apparently because the renal lesion improved.

Experimental evidence has been adduced to show:

(1) That the ingestion of supplementary protein leads to an increase in proteinuria, but only after a latent period of several days.

(2) That the increased proteinuria persists for a few days after the high protein diet has been discontinued.

These facts suggest a partial equilibrium between serum protein and that part of the deposit protein which serves as a reservoir of serum protein.

\section{BIBLIOGRAPHY}

1. Bassett, S. H., Elden, C. A., and McCann, W. S., The mineral exchanges of man. I. Organization of metabolism ward and analytical methods. J. Nutrition, 1931, 4, 235.

Bassett, S. H., and Van Alstine, H. E., The mineral exchanges of man. IV. Variations in the mineral content of diets with a constant raw weight formula. J. Nutrition, 1935, 9, 175.
2. Bloomfield, A. L., The effect of restriction of protein intake on the serum protein concentration of the rat. J. Exper. Med., 1933, 57, 705.

3. Boothby, W. M., Sandiford, I., Sandiford, K., and Slosse, J., The effect of thyroxin on the respiratory and nitrogenous metabolism of normal and myxedematous subjects. I. A method of studying the reserve or deposit protein with a preliminary report of the results obtained. Tr. A. Am. Physicians, 1925, 40, 195.

4. Cathcart, E. P., The physiology of protein metabolism. Longmans, Green and Company, London, 1921, 2d ed.

5. Czoniczer, G., and Weber, St., Die Wirkung der Eiweissreichen Nahrung bei Nephrose. Klin. Wchnschr., 1933, 12, 1566.

6. Deuel, H. J., Jr., Sandiford, I., Sandiford, K., and Boothby, W. M., A study of the nitrogen minimum. The effect of sixty-three days of a proteinfree diet on the nitrogen partition products in the urine and on the heat production. J. Biol. Chem., 1928, 76, 391.

7. Falta, W., Studien über den Eiweissstoff wechsel. II. Uber den zeitlichen Ablauf der Eiweisszersetzung im tierischen Organismus. Deutsches Arch. f. klin. Med., 1906, 86, 517.

8. Frandsen, J., Eiweissausscheidung bei chronischen Nephritikern. Acta med. Scandinav., 1926-27, 65, 341.

9. Hiller, A., McIntosh, J. F., and Van Slyke, D. D., The excretion of albumin and globulin in nephritis. J. Clin. Invest., 1927, 4, 235.

10. Holman, R. L., Mahoney, E. B., and Whipple, G. H., Blood plasma protein regeneration controlled by diet. I. Liver and casein as potent diet factors. J. Exper. Med., 1934, 59, 251.

Blood plasma protein given by vein utilized in body metabolism. II. A dynamic equilibrium between plasma and tissue proteins. J. Exper. Med., 1934, 59, 269.

11. Hooper, C. W., Smith, H. P., Belt, A. E., and Whipple, G. H., Blood volume studies. I. Experimental control of a dye blood volume method. Am. J. Physiol., 1920, 51, 205.

12. Keith, N. M., Rowntree, L. G., and Geraghty, J. T., A method for the determination of plasma and blood volume. Arch. Int. Med., 1915, 16, 547.

13. Keutmann, E. H., and McCann, W. S., Dietary protein in hemorrhagic Bright's disease. I. Effects upon the course of the disease with special reference to hematuria and renal function. J. Clin. Invest., 1932, 11, 973.

14. Lusk, G., The elements of the science of nutrition. Saunders, Philadelphia, 1928, 4th ed.

15. Mitchell, H. H., A method of determining the biological value of protein. J. Biol. Chem., 1924, 58, 873.

16. Mitchell, H. H., and Hamilton, T. S., The biochemistry of the amino acids. The Chemical Catalog Company, New York, 1929. 
17. Peters, J. P., and Bulger, H. A., The relation of albuminuria to protein requirement in nephritis. Arch. Int. Med., 1926, 37, 153.

18. Peters, J. P., Bruckman, F. S., Eisenman, A. J., Hald, P. N., and Wakeman, A. M., The plasma proteins in relation to blood hydration. VI. Serum proteins in nephritic edema. J. Clin. Invest., 1931, 10, 941.

19. Peters, J. P., and Van Slyke, D. D., Quantitative clinical chemistry. II. Methods. Williams and Wilkins, Baltimore, 1932.

20. Pomerenke, W. T., Slavin, H. B., Kariher, D. H., and Whipple, G. H., Blood plasma protein regeneration controlled by diet. I. Systematic standardization of food proteins for potency in protein regeneration. Fasting and iron feeding. J. Exper. Med., 1935, 61, 261.

21. Rose, M. S., Laboratory handbook for dietetics. Macmillan, New York, 1931.
22. Van Slyke, D. D., Rhoads, C. P., Hiller, A., and Alving, A. S., Relationships between urea excretion, renal blood flow, renal oxygen consumption, and diuresis. The mechanism of urea excretion. Am. J. Physiol., 1934, 109, 336.

23. Von Hoesslin, H., Klinische Eigentümlichkeiten und Ernährung bei schwerer Inanition. Arch. f. Hyg., 1919, 88, 147.

24. Weech, A. A., Goettsch, E., and Reeves, E. B., Nutritional edema in the dog. I. Development of hypoproteinemia on a diet deficient in protein. $\mathrm{J}$. Exper. Med., 1935, 61, 299.

25. Youmans, J. B., Wells, H. S., Donly, D., and Miller, D. G., The effect of posture (standing) on the serum protein concentration and colloid osmotic pressure of blood from the foot in relation to formation of edema. J. Clin. Invest., 1934, 13, 447. 